practitioner, more especially the younger members, after being schooled in the practice of antiseptic surgery, can often be as sure of obtaining primary union as the consultant and that without stitch abscesses. I myself do all my own oper tions and carrying out the precautions and directions given in Lockwood's "Aseptic Surgery" have obtained primary union in all cases-e.g., removal of adenoma from the breast, radical cure of hydrocele and hernia, removal of tuberculous glands in the neck, removal of dermoids over the eye, \&c. What more could any surgeon obtain? This belittling of the general practitioner leads to such a state of affairs as the following. A general practitioner is called to see a patient who has fractured the greater tuberosity of the humerus. The general practitioner informs his patient that his arm is broken and the patient at once says that he must have the best man down from London. A consultant comes down, the patient has an anæsthetic, his arm is examined, and the diagnosis is confirmed. Of course, the result is that much more effusion is thrown out which has to be got rid of by massage, \&c., and the consultant pockets a fee of 10,20 , or more guineas, practically for doing what was absolutely unnecessary and yet never sees the patient again. All the hard work and important massage, \&c., have to be done by the general practitioner with the result of a good useful arm.

Surely, if a general practitioner is enthusiastic over surgery and will take endless pains to get all his instruments, dressings, sutures, \&c., absolutely sterile and can be absolutely sure of primary union, why should he not attempt it? There are so many people who cannot afford a consultant's fee for operation and yet do not care to go into a hospital. Why should not the general practitioner take a smaller fee and give the patient as much satisfaction as if the operation were done in a hospital? The whole crux of the question, aseptic $v$. antiseptic surgery, is this, You cannot possibly do without using antiseptics and the best results, whether in hospital or private practice, are obtained by combination of both heat and chemicals as mentioned by both Mr. Watson Oheyne and Mr. O. B. Lockwood.

London, June 3rd, 1903. I am, Sirs, yours faithfully,

\section{SPITTING IN PUBLIC-HOUSES.}

\section{To the Editors of THE LANCET.}

Sirs,-In The Lancet of May 16th, p. 1401, Dr. Sidney Davies refers to public-houses as being fruitful sources of phthisis. Allow me to emphasise his remarks by drawing attention to another aspect of the same subject. There is a widely spread custom, especially in old inns, of using spittoons containing s and, sawdust, maltdust, \&c., which are dealt with in ways more or less insanitary. A few days ago while cycling I experienced an object lesson not easily forgotten. Outside a charming old inn was arranged a row of wooden spittoons. These, with their filthy contents, were placed on benches in the sun to dry and after a superficial sprinkling of sawdust were replaced in the bar, \&c. Such a condition is doubtless the result of ignorance and very simple measures need be taken to correct such misuse of the spittoon method of dealing with expectoration.

I am, Sirs, yours faithfully,

Devonshire-street, W., June 4th, 1903. WYaTt WINGRAVE.

\section{THE DIRTY FOUNTAINS IN TRAFALGAR- SQUARE.}

To the Editors of THE LANOET.

SIRs,-Will you kindly allow me to say a few words on this from the point of view of the design of such spaces in cities? For years I have seen these huge and ugly basins with regret and put down to our British toleration of ugliness that the most used of any open space in London should be so degraded. Apart from the filth of the water the square is wholly wrong from the point of view of good and simple design. If we are to have such breathing spaces in crowded cities surely it is only plain reason to ask that they be not merely to add to the areas of asphalte and stony surfaces with which we are already amply supplied? The mistaken idea of these huge fountain basins is taken from cities like Rome with a long and hot summer. Fresh and delicious water coming from the hills and tumbling into the hot places of Rome, supplying the people with water and cooling the hot streets, was a necessity, and Roman artists made their fountains worthy of their great use and of the city of Rome. But in our cool and moist country there is no need, artistic or other, for the introduction of huge water-basins of this character and we may see the hideous result in other places as well as Trafalgar-square-for example, the head of the Serpentine.

On the other hand, we have evidence, both in London and other cities, that such small places may be fresh and beautiful, even in the smoke. There is surely enough work for our architects to rebuild our houses and cities without despoiling open spaces which with a little thought and care might add to the beauty of the town. Even their own true work suffers as such " architectural gardening," as it is called, offers no relief to buildings as even poorly planted squares do. The spaces about Trafalgar-square are so wide and airy that there is not the slightest occasion to leave a wide spread of asphalte towards the middle. There might be two lines of trees on the upper têrrace and the tramps who now defile the whole place should be kept to that or some other fixed place and not occupy, as they do, the best place in the square. The warm side would be a happy place to grow the flowers that in our climate enjoy and need the sun. Even without any great change of plan the great basins would form noble flower-beds, but the best and most dignified way would be to make a clearance of the whole central block of asphalte, \&c., and plant trees and shrubs. Let anyone who looks at this square in its present state go and look at some of the smaller squares in the West Central district and then compare the effect. The gardening in the squares of London is the worst of any city in Europe-men digging and muddling about overgrown privet and like rubbish-yet the trees save the situation as they would Trafalgar-square. The effect need not be in any doubt, because we have plenty of evidence already that trees that thrive in London may adorn such places.-I am, Sirs, yours faithfully,

Lincoln's Inn-fields, June 8th, 1903.

W. ROBINSON

\section{THE USE OF THE SINGLE CUP AT THE CELEBRATION OF HOLY COMMUNION.}

\author{
To the Editors of THE LANCET.
}

SiRs,--In view of the interest which this subject is awakening and for purposes of information in a forthcoming local discussion on the subject I should be glad if any of your readers who have been able to trace the spread of disease to the promiscuous use of one cup at the celebration of Holy Communion would kindly place a record of their experience at the disposal of the public. I venture to think that there is a strong primâ-facie case against the use of one cup, but the task of the hygienic innovator would be made much easier if he could cite actual examples of contagion. I am, Sirs, yours faithfully,

Rochdale, June 9th, 1903. J. H. Brittain.

\section{PENAL CASES AT THE GENERAL MEDICAL COUNCIL.}

\section{To the Editors of THE LANCET}

SiRs,-Reading the report of the meeting of the General Medical Council in THE LANCET of last week I notice that at least two of the cases before the Council of charges of infamous conduct were adjudged not proven against the supposed offenders and the President in delivering judgment did not even caution these gentlemen, so that one may assume that the charges completely fell to the ground. I do not know precisely who or what person or body in either case was answerable for these gentlemen appearing before the Council, but it is quite evident that some person or persons outside of the Council must have laid these charges for the Council to adjudicate upon and that each of these practitioners must have been put to considerable expense to refute them, that they must have suffered great mental worry and been caused much trouble. There will be also in the minds of a great many a stigma attached to the names of these gentlemen which it will take some time to efface.

I want to ask, therefore, in the interests of the whole profession, if either, or both of these gentlemen, having been declared innocent of the charges made against them, has any redress? Can they ascertain who was responsible for the 